\title{
Clinical course of community-acquired respiratory syncytial virus pneumonia in newborns hospitalized in neonatal intensive care unit
}

\author{
Selmin KARADEMIR ${ }^{1}$ \\ Tamer YOLDAS ${ }^{1}$
}

${ }^{1}$ Clinic of Pediatric Cardiology, Ankara Dr. Sami Ulus Pediatric Health and Diseases, Training and Research Hospital, Ankara, Turkey

${ }^{1}$ Ankara Dr. Sami Ulus Kadın Doğum Çocuk Sağlığı ve Hastalıkları Eğitim ve Araştırma Hastanesi, Pediatrik Kardiyoloji Kliniği, Ankara, Türkiye
To the Editor,

With interest we read the article by Aydın et al. about "Clinical course of community-acquired respiratory syncytial virus (RSV) pneumonia in newborns hospitalized in neonatal intensive care unit" (1). We have the following comments and concerns.

The echocardiographic results of the patients were observed in this article. Secundum type atrial septal defect (ASD) has been noted in 7 patients. Four of them has been needed mechanical ventilation support. It has been noted that clinical course of RSV pneumonia was worse in patients with ASD. The authors also noted that ASD might negatively affect the course of the disease with increased viral load in lungs due to increased pulmonary blood flow.

RSV is a major cause of pneumonia in infants and young children worldwide (2-4). Pediatricians are using palivizumab prophylaxis in high risk infants to prevent RSV infection during RSV season. According to recommendations of American Academy of Pediatrics, congenital heart disease requiring palivizumab prophylaxis include cyanotic heart diseases, moderate to severe pulmonary hypertension and congestive heart failure requiring medication (5). In your study you think that ASD has been increased the disease severity due to increased pulmonary blood flow. We don't agree your discussion. Because; during fetal life, the majority of the blood reaching the left atrium comes via foramen ovale. Since there is minimal flow to the lungs. After birth, the lungs expand and the pulmonary blood flow begins to increase. The increased pulmonary venous return to the left atrium results in the left atrial pressure exceeding the right atrial pressure causing functional closure of the foramen ovale. Intrauterine physiology is not altered in the presence of an ASD, but ASD does not close with hemodynamic changes that occur following birth. Also, during the neonatal period and infancy right and left ventricular wall thickness are the same. The left to right shunt is small

\section{Yazışma Adresi (Address for Correspondence)}

Dr. Tamer YOLDAŞ

Ankara Dr. Sami Ulus Kadın Doğum Çocuk Sağlığı ve Hastalıkları Eğitim ve Araştırma Hastanesi,

Pediatrik Kardiyoloji Kliniği, ANKARA - TURKEY

e-mail: tameryoldas@gmail.com 
in patients with ASD in this period. During the infancy and early childhood the right ventricular wall becomes thinner and hence more compliant than that of the left ventricle, there is an increase in left-toright shunting. Thus, small ASDs result in trivial shunting and have no hemodynamic consequences. Larger defect are associated with substantial shunting, which may lead to volume overload of the right atrium, right ventricle and pulmonary arteries. Most patients with ASD are asymptomatic and may remain undiagnosed until later in life. Neonates or infants with ASD are not presented with features of pulmonary over circulation, recurrent respiratory infections and failure to thrive. Very rarely some neonates and infants may present with pulmonary over circulation. The mechanics of heart failure in these infants is not well understood since the hemodynamics are quite similar to those who are asymptomatic (6). Borow and Karp have proposed rapid remodeling and thinning of the pulmonary vascular bed to be the reason for this early presentation (7). For this reason pediatric cardiologists have not proposed the palivizumab prophylaxis in newborns and infants with ASD for prevention of RSV infection. We don't agree that ASD may increase the disease severity in RSV pneumonia. We have never seen pulmonary over circulation in the neonates with ASD who were followed at our clinic.

There is a mis identification in Turkish abstract. "Bu olgularda ASD daha ağır seyretmektedir" does not reflect the content of the article. It is not the same with each other in English and Turkish summary.

\section{REFERENCES}

1. Aydın B, Zenciroğlu A, Dilli D, Okumuş N, Ipek MS, Aydın M, et al. Clinical course of community-acquiredrespiratory syncytial virus pneumonia innewborns hospitalized in neonatal intensive care unit.Tuberk Toraks 2013;61:235-44.

2. Hall CB. Respiratory syncytial virus and parainfluence virus. N Egl J Med 2001;344:1917-28.

3. Simoes EA. Respiratory syncytial virus infection. Lancet 1999;354:847-52.

4. Hall CB, Walsh EE, Long CE, Schnabel KC. Immunity to and frequency of reinfection with respiratory syncytial virus. J Infect Dis 1991;163:693-8.

5. Committee on Infectious Diseases. From the American Academy of Pediatrics: policy statements-modified recommendations for use ofpalivizumab for prevention of respiratory syncytial virus infections. Pediatrics 2009;124:1694-701.

6. Sachdeva R. Atrial septal defects. In: Allen HD, Driscoll DI, Shaddy RE, Feltes TF (eds). Moss and Adams Heart Disease in Infants, Children, and Adolescents. $8^{\text {th }}$ ed. Philadelphia, Pa: Lippincott Williams \& Wilkins, 2013:672-91.

7. Borow KM, Karp R. Atrial septal defect-lessons from the past, directions for the future. N Engl J Med 1990;323:1968700 . 